\title{
JUSTICE AND OBJECTIVITY AS BALANCING PRINCIPLES
}

\author{
LIDIA RODAK* \\ PIOTR $\dot{Z}_{A K}{ }^{* *}$
}

\section{INTRODUCTION}

In recent jurisprudential literature, there have been fairly critical opinions of the predominant model of applying law in Polish courts. These opinions focus mainly on the way the in which law is interpreted but also concern the style of judging, the legal education system and even the ethos of lawyers. These criticisms pose great difficulties with the reception of European law and even put Poland's participation in the European community of legal interpretation in doubt.

To quote one of the critical authors: “(...) Polish lawyers, primitive positivists, are themselves bereft of the argumentative equipment to interpret law. They simply know how to apply rules, apparently with machine-like precision and lack of imagination; they do not presume that a new role in the social discourse is required both of them and, especially, of judges."1 Another author claims that there is little conception, neither among citizens nor lawyers, of law as an argumentative tradition, a discourse - mastery of which might enable disciplined, convergent but yet often novel legal responses to new situations. Rather, law is seen socially on one hand as a source of oppressive rules, and on the other as an opportunity for bonuses to be seized. In both cases. it is "still regarded as "received" and not resulting from negotiations or discussions' and is not recognized as a hermeneutic practice in which the citizens themselves are legitimately involved. ${ }^{2}$

DOI: $10.1515 /$ wrlae-2015-0024

* dr Lidia Rodak, Lecturer at the Department of Legal Theory and Philosophy of Law, Faculty of Law, Silesian University in Katowice.

**Piotr Żak, the Prosecutor in Regional Prosecutor's Office in Gliwice.

${ }^{1}$ Adam Czarnota and Martin Krygier, 'After Post-Communism - The Next Phase' (2006) 2 Annual Review of Law and Social Science 27-28.

${ }^{2}$ Marek Zirk-Sadowski, 'Transformation and Integration of Legal Cultures and Discourses Poland' in Wojciech Sadurski, Adam Czarnota, Martin Krygier (eds), Spreading Democracy and the Rule of Law (Springer Verlang Berlin 2005) 308-311. 
The same author also claims that, in Poland, legal positivism excludes the cultural context and the communicative role of law by assuming that the essence of law can be identified through the linguistic clearness of the legal texts. The level of language has to guarantee the reading of the text according to the intentions of the legislator. ${ }^{3}$ Other authors taking part in this discussion also highlight that judicial judgments, based mainly on formal standards, internal for law, apply legal rules according to their literal meaning or according to the interpretation that is commonly accepted by the community of lawyers. Such strict adherence to the rules and literal meaning of law could be seen as "unjust", or "not taking reality into consideration". From an analytical point of view, we can say that Polish judges do not take the principle of summum ius summa iniuria into account - they are ignoring circumstances outside the law. This strict formalistic approach can very often have a negative influence on the contemporary relevance of legal acts and constrains the flexibility of the regulations to be adapted in the context of a changing social and economic environment. It could also have a negative influence on the development of enterprise. ${ }^{4}$ To try and sum up the vision of the Polish judicature, it is worth recounting the opinion of one Polish judge: "the judges in lower instance courts take a strongly positivistic in their application of law; in the higher instances they represent a soft positivistic approach; while judges in the higher courts take the interpretative approach to the application of law seriously." In practice, this means that the majority of legal decisions are in accordance with a very positivistic and formalistic paradigm.

\section{II.}

The way of surmounting all these problems must be a change in the predominant intellectual paradigm of the Polish judiciary. It requires a transition from the traditional model, where the judge is the voice of the statute, to the contemporary model, where the judge decides the case based on more than the statute alone. ${ }^{6}$ In other words, a transition from the syllogistic model, based on hard rules, to the argumentation model, based on principles and soft rules. ${ }^{7}$ This requires judges to take general standards, principles, values and the general aims of law into account and not to apply them mechanically. Judges should also be conscious of axiological choices, which belong to the legislator. ${ }^{8}$ In such a model of law, the role of judges is

\footnotetext{
${ }^{3}$ Marek Zirk-Sadowski, Interpretation of law and its comprehension in Poland after the EU accession, 12 (paper presented at a conference in Gniezno, 26-29.09. 2004).

${ }^{4}$ Denis Galligan and Marcin Matczak, Strategie orzekania sądowego.O wykonywaniu władzy dyskre cjonalnej przez sędziów sądów administracyjnych $w$ sprawach gospodarczych $i$ podatkowych [Strategy of judicial decisions. About discretionary power completed by administrative court judges in economic and fiscal cases] (Warszawa 2005).

${ }^{5}$ Marek Zirk-Sadowski, Community of Judges (paper presented during The 9th International Roundtable for the Semiotics of Law, Poznan, 2010).

${ }^{6}$ Galligan, Matczak (n 4) 6.

${ }^{7}$ Lech Morawski, Główne problemy współczesnej filozofii prawa. Prawo $w$ toku przemian [Main problems of contemporary philosophy of law. Law during changes] (Warszawa 1999) 153.

${ }^{8}$ Lech Morawski, Zasady wyktadni prawa (TONiK 2006) 5.
} 
to find the best answer to the problem and the most rational and justified solution in the given circumstances. However, such an approach requires changes in both the frame of mind and the ethos of the judiciary.

As all the aforementioned authors indicate, judges taking decisions have to create new standards in such fields where it is not possible to find any. Deduction as a predominant style of justification has to be changed to a discursive style based on balancing arguments for and against. ${ }^{9}$ What the authors also stress is that a valuable pattern for taking such decisions could follow the justifications and reasoning of the Constitutional Tribunal.

The main characteristic feature of the non-syllogistic/contemporary model is that the conclusion (final decision) is not the effect of simple qualification/subsumption of a certain case under the conduct specified in a legal norm. The conclusion (decision) should be the effect of considering all factual and legal circumstances relevant in a given moment and also of balancing all arguments for and against a given outcome.

Generally speaking, the model of syllogistic legal reasoning could be characterized as a type of logical argument in which the proposition - the conclusion - is an individual decision expressing an individual norm which is inferred from two premises, namely the general, abstract legal norm and the sentence describing the empirical fact. According to the non-syllogistic model of legal reasoning, the proposition (conclusion) makes the effect of balancing values, goods and interests that are opposite to one other.

Let's consider an example, a case involving defamation claims where the problem boils down to the act of oral insult to religious cult objects by any slanderous communication, regulated by the art. 54.1 of the Constitution of the Republic of Poland. ${ }^{10}$

The question of the applicability of that norm would not be whether the behavior could be classified as exercise of freedom of expression or not. Rather, it would involve balancing out the principle of "freedom to express one's opinions" (art. 54.1) and other constitutional principles, such as the inherent and inalienable dignity of the person constituting the source of freedoms and rights (art 30. ) ${ }^{11}$ or the freedom of conscience and religion (art. 53). ${ }^{12}$

If the process of balancing indicates the priority of the principle set out in art. 54.1, the behavior described above is in accordance with Polish law. There is also the possibility of achieving an analogical effect through the interpretation of art. 54.1. The process of interpretation allows the opposing agreements to become balanced and harmonizes the conflicting norms (systemic interpretation) by considering the different effects of applying certain interpretation (the functional one). As long as interpretation can be identified along with the process of balancing, we may say that the

\footnotetext{
${ }^{9}$ Zirk-Sadowski (n 3) 2.

${ }^{10}$ Article 54. 1. The freedom to express opinions, to acquire and to disseminate information shall be ensured to everyone. 2. Preventive censorship of the means of social communication and the licensing of the press shall be prohibited. Statutes may require the receipt of a permit for the operation of a radio or television station.

${ }^{11}$ Article 30 The inherent and inalienable dignity of the person shall constitute a source of freedoms and rights of persons and citizens. It shall be inviolable. The respect and protection thereof shall be the obligation of public authorities.

${ }^{12}$ Article 53 Freedom of conscience and religion shall be ensured to everyone.
} 
application of law still takes place in accordance with the syllogistic model of argumentation. The differences between these two models could relate to the different styles of justification of the delivered decision, where the focus is shifted from deduction to discourse. That is why there is no necessary link between the application of principles and the syllogistic model of argumentation. There can be no doubts that those who juxtapose one model against the other accept that the argumentative model allows one to take "right decisions" not only by "correcting law" but also proceed in accordance with legal norms interpreted from the point of view of juridical activism - thus not necessarily directly.

\section{III.}

In order to grasp a deeper understanding at this point, we will set out the basic conceptual differences between rules and principles ${ }^{13}$ and the roles they play in the application of law. Generally speaking, rules are a type of legal norm that should be applied in an all-or-nothing way, terium non datur. These kinds of norms prescribe taking certain actions, or propose a rather mechanistic way of finding solutions. Principles ${ }^{14}$, on the other hand, do not have to be applied mechanically. They have to be taken into consideration as argumentative reasons which suggest the direction in the decision of a case. Principles can fulfill a wide range of different needs depending on the legal and factual circumstances they are applied to. ${ }^{15}$

The decision-taking process based on the principles, in opposition to the traditional, syllogistic model, does not take its decisions from legal norms; they are the results of balancing (Abwägung) opposite or competing principles. ${ }^{16}$ Taking decisions according to the argumentation model is mainly, or even entirely, reduced to the adequate balancing of the principles and aims of law. ${ }^{17}$ One author proposes that it is applying soft law, based mainly on balancing principles, within a rational discourse. ${ }^{18}$ This balancing

\footnotetext{
${ }^{13}$ Herbert L. A. Hart, The Concept of Law (Oxford, Clarendon Press 1997) 259.

${ }^{14}$ It should be stressed that the understanding of the principles which has been presented here is far different from what the linguistic tradition suggests. According to the concepts described above, the directive "ne bis in idem" is a rule, since it can be either followed or not. 15 Josef Esser, Grundsatz und Norm in der richterlichen Rortbildung des Privatrechts (Tübingen, 1956); Ronald Dworkin, Seriously interpreting laws (Warszawa, PWN 1998) 56; Robert Alexy, Theorie der Grundrechte (Baden-Baden 1985) 71; also Robert Alexy, 'On the Structure of Legal Principles' (2000) 13 (3) Ratio Juris 294; Tomasz Gizbert-Studnicki, Zasady i reguly prawne [Principles and legal rules] (1988) 3 Państwo i Prawo 68.

${ }^{16}$ Ota Weinberger, 'Prima Facie Ought. A Logical and Methodological Enquiry' (1999) 12 (3) Ratio Juris 239: "Rules stating principles or purposes are always applied as views determining the decision by weighing (but not by subsumption) (...)".

${ }^{17}$ Bartosz Wojciechowski, 'Dyskursywny model sądowego stosowania prawa - wybrane aspekty' [A discursive model of judicial law enforcement - selected aspects] in Jerzy Stelmach (ed), Filozofia prawa wobec globalizmu [Philosophy of law towards globalism] (Kraków 2003) 153.

${ }^{18}$ Zirk-Sadowski (n 3), 13; See also Marek Zirk-Sadowski, Instytucjonalny i kulturowy wymiar integracji prawnej [Institutional and cultural dimension of legal integration] in Leszek Leszczyński, Zmiany społeczne a zmiany $w$ prawie. Aksjologia, konstytucja, integracja europejska [Social changes and legal changes. Axiology, constitution, European integration] (Lublin, 1999) 41; Piotr Tuleja, Normatywna treść praw jednostki $w$ ustawach
} 
operation - with arguments "for" or "against" the competing interests - means that system of law is going away from the deductive way of applying law (i.e. the subsumbtion model). ${ }^{19}$

One of the central problems of the argumentation model is the objectification of the criteria used to balance competing standards, that is to say principles, values, aims. In this case, it is not possible to use rules like lex posterior or lex superior, which would enable us to make principled choices between rules as to their adequacy or appropriateness.

One of the most famous directives in Polish jurisprudential literature, used in cases of conflicting rules, is the "Weight Formula" conceptualized by Robert Alexy (Abwägungsgesetz, also known as the process of balancing or weighing). According to the Weight Formula: "the higher the level of infringement or non-fulfillment of one of the conflicting principles then the more important is implementation of the other principle". ${ }^{20}$ It is very important to mention the universal character of this principle, which exists mainly because of its formal character. This principle is not able to indicate either how to establish the degree of infringement or how important the conflicting principles are.

According to Robert Alexy, the practical importance of the principle of conflict solving appears through the principle of proportionality. This principle should be the basis of arguments that, to a certain degree, could satisfy competing principles. The principle of proportionality can be established by a deductive process as this is a property of the principle itself. ${ }^{21}$ Other authors indicate that the conflict of principles has to be decided according to the principle of proportionality ${ }^{22}$ because it allows for a very

konstytucyjnych RP [The normative content of individual rights in the constitutional laws of Poland] Wydawnictwo Sejmowe (Warszawa 1997) 127.

${ }^{19}$ Wojciechowski (n 17) 166.

20 Alexy, Theorie (n 15) 146; ““‘(...) Diese Äußerungen deuten auf eine für die Abwägungen des Bundesverfassungsgerichts konstitutive Regel hin, die folgendermaßen formuliert werden kann: Je höher der Grad der Nichterfüllung oder Beeinträchtigung des einen Prinzips ist, um so größer mu $\beta$ die Wichtigkeit der Erfüllung des anderen sein. Diese Regel drückt ein Gesetz aus, das für die Abwägung von Prinzipien gleich welcher Art gilt. Es kann als $<$ Abwägungsgesetz $>$ bezeichnet werden. Nach dem Abwägungsgesetz hängt das zulässige $\mathrm{Ma} \beta$ der Nichterfüllung oder Beeinträchtigung des einen Prinzips vom Wichtigkeitsgrad der Erfüllung des anderen ab. Bereits in der Definition des Begriffs des Prinzips wurde mit der Klausel <relativ auf die rechtlichen Möglichkeiten> das, was durch das jeweilige Prinzip geboten wird, in eine Relation zu dem, was durch gegenläufige Prinzipien geboten wird, gesetzt. Das Abwägungsgesetz sagt, worin diese Relation besteht. Es macht deutlich, da $\beta$ das Gewicht von Prinzipien nicht an sich oder absolut bestimmbar ist, sondern da $\beta$ stets nur von relativen Gewichten die Rede sein kann“. See also Tomasz Gizbert-Studnicki, 'Conflict of goods and conflict of norms '(1989) 1 RPEiS 10; Krzysztof Płeszka, Justifying interpretative decisions by their consequences (Kraków 1996) 179; Tuleja (n 1) 72; Bartosz Wojciechowski (n 17) 161.

21 Alexy, Theorie (n 15) 297.

${ }^{22}$ Mirosław Wyrzykowski, Pojęcie interesu społecznego w prawie administracyjnym [The notion of social interest in administrative law] (Warszawa 1986) 177; Andrzej Grabowski, Tomasz Gizbert-Studnicki, 'Normy programowe w konstytucji' [Programme norms in constitution] in Janusz Trzciński, Charakter $i$ struktura norm konstytucji [Character and structure of constitutional norms] (Warszawa 1997) 109; see also judgment of the Constitutional Tribunal 28th May 1997 (K. 26/96) 193, where the Constitutional Tribunal stated that legalisation of a given resolution of collision of goods is dependent on preserving the constitutional criteria of resolving such collisions by the legislator, in particular by 
comprehensive analysis of the case. The architecture of the judges' legal argumentation consists of a comprehensive analysis of the situation, taking into account all elements and conditions operating outside the law such as technical or economic, for example. ${ }^{23}$

The principle of proportionality is formal one which is why, as one author rightly claims, there is no real difference between proportionality and the balancing formula. ${ }^{24}$ The formal character of the principle makes it universal and valid every time it is specified in any particular case. However, the decisions based on this formal principle could be very dissimilar in different cases. ${ }^{25}$

\section{IV.}

To postulate that certain values (principles) should be assessed according to the proportionality of their weight has its own justification in the concept of justice. It is a simple realization of what justice demands ${ }^{26}$ in accordance with the Aristotelian definition of "justice as the distribution of certain goods." 27

The literature also highlights that balancing is very tempting because it is consistent with the common understanding of justice as fairness and reasonableness. Themida - the Goddess of Justice - is blindfolded and holds a sword in one hand and scales in the other. She is weighing up all "for" and "against" arguments to decide which party prevails. ${ }^{28}$ Supposing we say that today's Justice is holding a calculator in her hand, pretending to do some very

preserving the proportionality rule; see also judgment of the Constitutional Tribunal of 28th May 1997 (K. 26/96) 199.

${ }^{23}$ Galligan and Matczak (n 4) 44.

${ }^{24}$ Lothar Hirschberg, Der Grundsatz der Verhältnismässigkeit (Göttingen 1981) 91.

${ }^{25}$ ibid 86.

26 ibid ““‘(...) Grundsatz der Verhältnismäßigkeit und Zweckformel, Prinzip des überwiegenden Interesses und Güteraabwägungsprinzip (...) wie auch weitere denkbare allgemeine Formeln sind deshalb nur sprachliche Variationen über ein und dasselbe Thema der Fallgerechtigkeit"; Chaim Perelman, O sprawiedliwości, [About justice] (Warszawa 1959) 130: ““(...) proportionality should be applicable for all forms of justice, and its categories should create a system, which would allow to compare them from a given viewpoint. For instance, in criminal law punishment should be compatible with the committed offence, so that penal regulation were just, in other words deprived of arbitrariness, because rationally justified ".

${ }^{27}$ Aristotle, The Nicomachean Ethics, "The justice with which we are concerned has two branches: distributive, of honours and the like among citizens by the State, and of private property by contract and agreement; and corrective, the remedying of unfair distribution. There are always two parties, and justice is the mean between the unfairness which favours A and the unfairness which favours B. Distributive justice takes into consideration the merits of the parties; corrective justice is concerned only with restoring a balance which has been disturbed. The distribution is a question not of equality, but of right proportion; and this applies to retribution, which is recognized as one of its aspects, e.g. the retribution for an officer striking a private and for a private striking an officer. Proportional requital is the economic basis of society, arrived at by the existence of a comparatively unfluctuating currency, which provides a criterion.

${ }^{28}$ Thomas Alexander Aleinikoff, 'Constitutional Law in the Age of Balancing' (1987) 96 (5) The Yale Law Journal 962. 
sophisticated analyses. "Balancing provides a careful, sensitive, and thoughtful way to dispense justice, to give each his or her due." 29

The function of correction in the hard definition of justice is taking all individual circumstances into account as a way of optimalizing the final decision in a case. Fairness is a type of corrective device for justice. ${ }^{30}$ Fairness, as Ch. Perelman claims, has to have a function of supporting justice to see that it's implemented in a necessary way. ${ }^{31}$

It is the role of the judge, in his or her own competence, to evaluate each of the principles and assign values to the identified interests. He or she has the right to make one principle more important and decide which one will be implemented.

The balancing process has to be flexible and relevant to individual circumstances. It has to reject absolutist solutions because there is no such thing as objective criteria, which is necessary in providing absolutist solutions. To eliminate everything arbitrary is possible when there is common agreement in the matter of values within the normative system. As Perelman claims, because of the arbitrary and mutually contradictory character of the values in any legal system, there is no possibility of perfect justice based entirely on reason. ${ }^{32}$ Very often, arguments for one solution are balanced by arguments against it, or for the opposite solution. It is very rare to observe the evaluation of arguments based on measure or on account. Evaluations can be changed according to subject and the decision-making process carries a personal shadow" 33 .

\section{V.}

One can say that balancing values boils down to the application of distributive justice. Primacy of justice, fairness and functionality over the norms of positive law has always been stressed by the followers of the doctrine of judicial activism. Positive law is not treated as the only element that determines the final decision and the judicial activity is approached as a creative process.

\section{VI.}

The best example of the argumentative model of law is represented by the Polish Constitutional Tribunal. Because of its importance to the state,

\footnotetext{
29 ibid 962.

${ }^{30}$ Henryk Piętka, Stuszność $w$ teorji i praktyce [Justice in theory and practice] (Warszawa 1929) 33; Imre Szabó, Pojęcie stuszności w różnych systemach prawnych [The notion of justice in different legal systems], (1971) 5 Law and State 673-680.

31 Perelman, O sprawiedliwości (n 26) 64 (Justice at raison).

32 ibid 105-107.

33 Chaim Perelman, Logika prawnicza. Nowa retoryka [Legal logic. New rhetorics] (Warszawa 1984) 36 (Logique juridique).
} 
political bodies are very sensitive about its position and have to take the Tribunal's views into account. ${ }^{34}$ The Polish Constitutional Tribunal believes that a strong, independent and separate constitutional court is essential to protect the constitution, the rule of law and liberal values more generally. The stronger this is, the more effective it is at keeping the political branches of the government within constitutional bounds. ${ }^{35} \mathrm{We}$ can also witness that judicial activism has an increasingly significant role nowadays and that the Constitutional Tribunal takes part in the most important fundamental ideological and political debates and conflicts. Very often, the Tribunal has its own agenda, which may not be compatible with the agendas of other branches of power, namely Parliament and Government. Judges in the Constitutional Tribunal have no political responsibilities but, at the same time, often decide on very important social and economic matters. That is why a lot of problems can be seen in jurisprudence regarding the balancing of constitutional matters. Following pragmatic instrumentalism, the Constitutional Tribunal gives no guarantee that its own decisions will provide better balancing than the legislator. The central point of the criticism against the constitutional jurisdiction is that, when they cross the border of the division of power, they remove part of the competences that a democratic society gives to the legislator. ${ }^{36}$ It seems that the balancing should belong mainly to the legislator due to the conditions of democratic representation give the legislator the greatest chance to take into account and to balance all different interests.

\section{VII.}

There is also quite popular opinion that balancing and taking decisions on the basis of principles is characteristic of a certain branch of law. ${ }^{37}$ Distinctiveness in the jurisprudence of the Constitutional Tribunal and the European Court of Justice is determined by the character of the statute, which is the subject of interpretation. What can be highlighted here is that the American doctrine distinguishes between constitutional interpretation and statutory interpretation. The difference is that constitutional interpretation concerns fundamental matters, whereas statutory interpretation concerns mainly interpretation of rules. ${ }^{38}$ It is also possible to apply the same division to community law and state law. The former is based mainly on principles and talks about aims and directions; the latter concerns the interpretation of rules. That is why the interpretation of both types of regulations has to be different. ${ }^{39}$

\footnotetext{
${ }^{34}$ Czarnota, Krygier ( n 1) 30.

35 ibid 31 .

36 Aleinikoff (n 28) 962, 985; see also Józef Nowacki, “Klauzula „państwo prawne” a orzecznictwo Trybunału Konstytucyjnego' [The clause "legal state" and judicial decisions of the Constitutional Tribunal] in Józef Nowacki, Studia z teorii prawa [Studies in theory of law] (Zakamycze 2003) 41-57.

37 Józef Nowacki and Zygmunt Tobor, Wstęp do prawoznawstwa [Introduction to Law] (Kraków, Zakamycze 2002) 103.

${ }^{38}$ Lech Morawski, Remarks on the contemporary interpretation of law (paper presented at a conference in 26-29.09 Gniezno 2004, 4) 6.

39 Zirk-Sadowski, Interpretation of law (n 3 ) 4.
} 
One could say that the judges of the Constitutional Tribunal are making their decisions based on economic or ethical arguments using general principles because of the general clauses and evaluative terms of the legal regulations ${ }^{40}$. On the other hand, judges of the European Court of Justice are forced to use general principles and informal standards in their decisionmaking due to the lack of the comprehensive legislation. That is why this institution has to create and develop community law. It is beyond doubt that the method of interpretation of legal texts is dependent on the character, content and aims of the texts. It is also necessary to take all the traditional interpretative directives into consideration. Another determinant is the type of court making the decision, because it is possible to observe that the higher courts are willing to give more activist decisions than the lower courts. This is connected with the possibility of appealing against the courts' decisions. ${ }^{41}$

\section{VIII.}

Take this example. One judge, following his personal convictions, exculpates the doctor who has performed an abortion. The doctor acted against the actual legal regulation(s) and his main motivation was also his deep personal conviction that it is the right of every woman to decide about their own bodies. In another very similar example, we have the opposite situation. The judge sentences the doctor who has performed the abortion, even though the circumstances involved rape and imminent danger to the woman's life. The motivation of the judge is also his deep conviction that human life has to be protected from the very beginning. Both the first and the second example could be justified in light of Article 38 of the Polish Constitution. This article says that every human being has a right to protection of his/her life provided by the Republic of Poland.

It is seems that the judge who follows his/her own deep convictions participates in the axiological choices when sentencing somebody, despite the lack of criminal character of the act. It is also hard to imagine the opposite situation e.g. that the judge exculpates somebody because of his/her different moral convictions.

As one of Polish author claims: "when the Constitutional Tribunal gives its own opinion about whether certain a certain legal regulation is constitutional or unconstitutional, they are giving priority not to the Constitution but to their own opinion, preferences and evaluation. The Tribunal has its own policy, different than the legislator's, though it judges in the same as if it was the legislator." 42

\footnotetext{
40 Aleinikoff (n 28) 995.

41 Tomasz Spyra, Granice wykładni prawa: znaczenie językowe tekstu prawnego jako granica wyktadni, [Boundaries of interpretation of law. Linguistic significance of legal text as a Bondary of interpretation of law] (Kraków, Zakamycze 2006) 209.

42 Józef Nowacki, 'Wartości sądowe w orzecznictwie Trybunału Konstytucyjnego' [Court values in the judicial decisions of the Constitutional Tribunal'] in Józef Nowacki (ed), Rzady prawa [Rules of Law] (Katowice 2004) 350.
} 
IX.

Trying to grasp the essence of objectivity with regard to its legal usage, in particular, the way judges use it to justify legal decisions paints a very surprising picture. Even on a very general level, the picture of objectivity painted in jurisprudence (law in books) appears to be quite different from that which appears in court rulings (law in action). Overall impressions from empirical analysis suggest that objectivity has become a construct, devoid of its original rigid meaning (which was mostly identified with truth and universality). Users of this term seem to fill it with their own and often very different meanings. It now resembles a type of intellectual invention designed to work and act in its inventors' own argumentative interest.

What judges perceive as right, correct, proper, rightful, legitimate, equitable or reasonable, and what they finally agreed to accept, have all been called objective. The key question here is whether decisions, evaluations and legal facts become objective by the power of naming them as 'objective' by legislators, courts or judges; or are certain legal decisions, opinions and evaluations called 'objective' because they have an intrinsic objective quality? If it was possible to state unambiguously what objectivity means, it might be possible to at least provide a hypothetical answer to this question. But, in light of the ambiguity of meanings, it seems impossible to give one clear answer. On the other hand, we have opinions, judgments, legal facts, etc. ${ }^{43}$ which have been recognized as objective and, as such, serve to find the "right place" in the process of justification.

This reductionist division of what is objective and subjective is highly controversial. There is a huge grey area between subjective opinion and its objective opposition. This point of view is confirmed by jurisprudential literature which says that without making consideration of objectivity more precise, the potential for abuse is opened up as objectivity is a notion that has great argumentative strength.

It is important to explain the most common aims when employing the terminology of "objective judgments" or objective criteria. The adjective "objective" is used as the guarantee of eliminating the arbitrary character in judgments. When the evaluation is objective, it means that it's not the result of an individual judgment. It is not subjective or, at least, other people will share the same subjective point of view. Legal literature emphasizes the necessity of objectification, but also points out its weaknesses and even the impossibility of reaching this position. The objective test is based on reasonableness, which has to be determined at the judges' discretion. But as A. Barak, one of the judges, also stresses is that "when the judge describes a reasonable person, in most cases he is thinking of himself. Yet nothing could be further from the truth." "If we accept that it's impossible to be free of an individual perspective, what is presented as an objective or rational standpoint is the judge's process of rationalization when exercising judicial discretion.

What then is the real role of rationalization and what is the difference between objectification and rationalization, if any? Could the process of

\footnotetext{
${ }^{43}$ It is difficult to distinguish specific objects that are called objective. As objective are described very different types of referential subjects, even those that contradict common intuition, such as "objective evaluation."

${ }^{44}$ Aharon Barak, Judicial Discretion (New Haven, Yale University Press 1989) 125.
} 
rationalization be treated as the process of translating or transforming what is subjective into what is objective? The important accent is between translating and transforming.

It seems that in many cases of examined judicial discretion, the objectification process is merely the description of how it was carried out. However, is it enough to call something objective by making it open to public view and giving it an explanation and a justification? This objectification, in practical terms, brings the necessity of the transformation from subjective to objective, from personal or individual to common and is more like a process of transformation than translation. What undoubtedly has to be stressed is that the category of objectivity plays a special role in the application of law. Some not only criticize its role from an ideological point of view but also view it as a tool of oppression. Followers of Feminist Jurisprudence call for a complete rejection of objectivity, describing it as a 'hypocritical notion'. They mainly highlight the internal incoherence of objectivity. As they explain, there is a clash between rules and norms, which are perceived as objective, and the practice, which makes objective rules and norms fail when they are judged by implicit standards. ${ }^{45}$ The only remedy for this tension between explicit and implicit standards is to reject the notion of objectivity, as the Feminist Movement claims. The theme of rejecting objectivity is also prevalent in followers of the Critical Race Theory (CRT). Fundamentally, they share the same objections to the use of objectivity in law as the Feminist Movement. This American movement is skeptical about concepts such as justice, truth and reason, since they reveal their complicity with power. ${ }^{46}$ They attempt to expose the manner in which these ideas are 'racialised' in American law ${ }^{47}$. The Critical Race Movement typically shifts the perspective of consideration from the objective to the subjective level. Using a storytelling model, utilizing subjective accounts of experiences of racism, they seek to challenge mainstream cultural assumptions.

In spite of much criticism, objectivity fulfills an important bridge or meeting point between the formal and substantive elements of legal systems. At the very basic level of legal assumptions, objectivity provides values that constitute law, like certainty, the public and positive character of the law, its universality and generality, its autonomy ${ }^{48}$, legitimacy, methods of legal justification and its power of authority. In this sense, objectivity could be perceived as a necessity in law. It is not possible to think about law without objectivity or, more precisely, the ideas represented by the concept of objectivity, which are transparency, common acceptance, legal certainty, universality, equity before law, and, in a sense, democracy. These ideas create a group of formal conditions as the elements of the legal system. However, objectivity is also understood as justice or fairness, its meaning here referring to the material, substantive elements of law.

\footnotetext{
${ }^{45}$ Catherine MacKinnon, Toward a Feminist Theory of the State (Harvard University Press 1989) 54.

46 Angela P. Harris, 'Foreword: The Jurisprudence of Reconstruction' (1994) 82 California Law Review 741, 743.

${ }^{47}$ Derrick Bell, And We Are Not Saved: The Elusive Quest for Racial Justice (New York: Basic Books 1987).

${ }^{48}$ The features that constitute legal order, rules of law, according to Under in Law in Modern societies.
} 
This is broadly the key for the analysis of both models of applying law, where tension appears between the formal demands that are provided by the syllogistic model and substantive elements that are represented in the argumentative model of legal systems.

An assessment of the objectivity of legal decision-making will provide a deep insight into the legal reasoning behind judicial decisions; for example, how objectivity forms part of both the argumentative and syllogistic model. It seems that the use of objectivity is linked to different ideologies in the application of the law, namely the models of judicial restraint and judicial activism. While the main desirable attribute of the former is that of legal certainty, the latter's attributes include fairness, justice and morality, based on legal principles and specific to the circumstances of particular cases. This suggests that, while objectivity is present in both of these judicial approaches, its meaning and application are different depending on the ideological underpinnings of the model. In order to find out how different types of objectivity deal with different ideologies of applying law, it is necessary to identify what conceptualization is.

Objectivity is the concept that proposes a certain vision of reality; this is mostly identified with the doctrine of realism. However, the doctrine of realism is very complex and in the absolute version very hard to uphold. That is the main reason why you can distinguish many types of realisms. ${ }^{49}$ Following the process of diversity, the concept of objectivity started to lose its original meaning and gain new content. Objectivity has been used in many different contexts and types of discourses, and through this, has gained new meanings to the extent that it is even possible to speak about objectivity in antirealist terms. "Objectivity" can now be seen as a graded concept which can be broadly defined as having "strong", "modest" and "minimal versions". ${ }^{50}$ The strong or realistic approach I will treat as a representation of the rationality of the Age of Enlightenment, the modest and minimal versions as the representation of postmodern philosophy.

A common core of all these understandings of objectivity is the principle of decreasing the relation of objectivity in regard to the subject, mutatis mutandis, and increasing the autonomy of objectivity. If you understand objectivity as connected with the object and subjectivity as related to the subject, it is necessary to explain all those usages of objectivity that are related to the increasing role of the subject's activity and still named as objective.

In the jurisprudential literature, it is possible to find examples of strong, modest and minimal objectivity. If we divide these distinctions into two groups according to the activity of the subject, the first group will be entirely connected with the object, namely the strong version of objectivity, and the second connected with an increasing role of the subject, namely the modest and minimal versions of objectivity.

Strong objectivity, as completely independent from the subject, is characterized as pure objective entity. Strong objectivity is the representation of the theory of realism, which rejects the subject's dependence in regard to

\footnotetext{
${ }^{49}$ Jan Woleński, Epistemologia [Epistemology] (Warszawa, Wydawnictwo Naukowe PWN 2005) 465.

${ }_{50}$ Connie S. Rosati, 'Some puzzles about objectivity of law' (2004) 23 (3) Law and Philosophy.
} 
existence and perception: for example, a stone which exists completely independently from the subject or any of their activity, no matter whether the subject perceives it or not.

The other two approaches of objectivity are connected with the activity of the subject, which is necessary and impossible to eliminate. The modest version of objectivity is characterized in regard to subject, determined by the ideal epistemological conditions (as I will later explain). These conditions have to be fulfilled to make it possible to think about objectivity as in some way independent of the subject. In this sense, for example, the activity of measuring could be objective. The effects of measuring would be the same for everybody who is doing it under the same conditions. One can observe that, within the same group of notions, it is possible to find different extensions of the subject's indeterminacy. This is possible because the minimalization of the subject's intervention is not always possible to the same degree and there are situations when objectivity is desirable. The example of measuring is one of the strongest but there are there a lot of situations in which it is impossible to eliminate the subject's determination to any large extent. All of these cases could be situated between the minimal version of objectivity and the strongest modest version. The minimal version of objectivity is based on the acceptance of the majority in a certain group. Take fashion as an example. What is fashionable in a certain society or group is accepted by the majority of that group. ${ }^{51}$ Both modest and minimal versions of objectivity could be characterized as an attempt to minimalize subjective elements, but with the reservation that subjective elements are not excluded entirely. It is important to point out that on the semantic, epistemological and ontological levels, there are these three types of objectivity.

It seems that problems with objectivity in the process of applying the law mirror the shifting between argumentative and syllogistic style of justifying decisions. The former is tied with objectivity in a strong sense, mostly identified with truth. The latter is closer to objectivity in the modest or minimal version. Modest or minimal objectivity is characteristic of the non-syllogistic model of decision making, not only those based on balancing values, but also those decisions that search for justification in common agreement, or as an effect of rational discourse (Habermas). The balancing formula, as is represented by the principle of proportionality in Polish jurisprudence, fulfils the condition of objectivity in a modest sense - the decision is related to the criteria that allows for objectification.

Both the syllogistic model and objectivity in its strong version raise many objections in practical legal discourse. They are very successful when playing the role of pragmatic form of argumentation as they provide arguments that are often very convincing and finally accepted. However, the assumptions which are necessary for the application of both these models do not hold up in the normative discourse. The elements of the syllogistic model are based on evaluative judgments and have no formal value; you cannot talk about formal implication or valid conclusions within the syllogistic model. Objectivity, in a strong sense, is based on the assumptions of strong realism which are highly controversial, not only in legal contexts, but when applied to humans generally and even to natural sciences.

${ }^{51}$ ibid 275. 
That is why the application of either of these models is highly problematic in normative contexts.

\section{$\mathbf{X}$.}

How is the objectivity of the decision to be understood? In the syllogistic model, to put it in judicial language, objective criteria are those which are included expressis verbis in legal norms, directives intended by the legislator. Such objective norms are independent from and external to the judge who gives the decision.

In the argumentative model, the process objectification of the decision process is different and is more based on openness and transparency, which makes all arguments open to the public. Where syllogistic reasoning is not applied, the motives and reasons taken into account have to be revealed in order to make proper justification of the delivered decision. Syllogistic reasoning, thanks to its formality and rigors, does not require more elucidation. Quite contrarily, in order to be accepted, the argumentative model needs to show due standards of its application with convincing justification. This is the way to attain accountability in the discursive model.

In conclusion, one can say that the process of objectification is differently understood in both models of legal reasoning. This phenomenon is the effect of different conceptions of objectivity applied in the legal discourse. One can say that in the syllogistic model the strong conception of objectivity is relevant, while in the argumentative one the modest or the minimal conception of objectivity is suitable, depending on which argumentative models are to be applied. In the former one, the judge is only the mouth of the statute which has to be applied, while the latter one needs judicial involvement and acceptance of his decision has to be gained. The process of decision-making based on ultimate principles involves the application of equity rules, while verification of such decisions (objectification of criteria relevant for the decision) could only take place by their proper justification disclosed to the general public. One can say that transparency can assure more responsibility from courts.

\section{CONCLUSIONS}

The problems we have outlined closely resemble the disputes between the followers of the doctrine of judicial restraint and the doctrine of judicial activism. The common feature of both models is that they indicate certain values that are desired in applying law. The main desirable value of the doctrine of judicial restraint is the certainty of the law. With judicial activism, it is fairness, justice, morality and the ability to follow the particular circumstances of each case using the general principles of morality and justice. The dispute between the traditional and the modern models of applying law, in other words between the syllogistic model, based on subsumption, and the argumentative model, based on balancing, seems to primarily be a dispute about values. 


\section{References}

Aleinikoff T. A., 'Constitutional Law in the Age of Balancing' (1987) 96 (5) The Yale Law Journal.

Alexy R., 'On the Structure of Legal Principles' (2000) 13 (3) Ratio Juris Alexy R., Theory der Grundrechte (Baden-Baden 1985)

Aristotle, The Nicomachean Ethics.

Barak A., Judicial Discretion (New Haven, Yale University Press 1989).

Bell D., And We Are Not Saved: The Elusive Quest for Racial Justice (New York: Basic Books 1987). .

Czarnota A. and Krygier M., 'After Post-Communism - The Next Phase' (2006) 2 Annual Review of Law and Social Science.

Dworkin R., Seriously interpreting laws (Warszawa, PWN 1998)

Gizbert-Studnicki T., 'Conflict of goods and conflict of norms '(1989) 1 RPEiS.

Gizbert-Studnicki T., Zasady i reguty prawne [Principles and legal rules] (1988) 3 Państwo i Prawo.

Grabowski A., Gizbert-Studnicki T., 'Normy programowe w konstytucji' [Programme norms in constitution] in Janusz Trzciński, Charakter i struktura norm konstytucji [Character and structure of constitutional norms] (Warszawa 1997)

Hirschberg L., Der Grundsatz der Verhältnismässigkeit (Göttingen 1981).

MacKinnon C., Toward a Feminist Theory of the State (Harvard University Press 1989). Harris A.P., 'Foreword: The Jurisprudence of Reconstruction' (1994) 82 California Law Review.

Morawski L., Główne problemy współczesnej filozofii prawa. Prawo w toku przemian [Main problems of contemporary philosophy of law. Law during changes] (Warszawa 1999).

Morawski L., Remarks on the contemporary interpretation of law (paper presented at a conference in 26-29.09 Gniezno 2004, 4) 6.

Morawski L., Zasady wyktadni prawa (TONiK 2006). Hart H. L. A., The Concept of Law (Oxford, Clarendon Press 1997). Esser J., Grundsatz und Norm in der richterlichen Rortbildung des Privatrechts (Tübingen, 1956).

Nowacki J. and Tobor Z., Wstęp do prawoznawstwa [Introduction to Law] (Kraków, Zakamycze 2002).

Nowacki J., 'Klauzula „państwo prawne” a orzecznictwo Trybunału Konstytucyjnego' [The clause "legal state" and judicial decisions of the Constitutional Tribunal] in Józef Nowacki, Studia z teorii prawa [Studies in theory of law] (Zakamycze 2003).

Nowacki J., 'Wartości sądowe w orzecznictwie Trybunału Konstytucyjnego' [Court values in the judicial decisions of the Constitutional Tribunal'] in Józef Nowacki (ed), Rządy prawa [Rules of Law] (Katowice 2004).

Perelman Ch., Logika prawnicza. Nowa retoryka [Legal logic. New rhetorics] (Warszawa 1984) 36 (Logique juridique).

Perelman Ch., O sprawiedliwości [About justice] (Warszawa 1959). 
Piętka H., Stuszność w teorji i praktyce [Justice in theory and practice] (Warszawa 1929).

Płeszka K., Justifying interpretative decisions by their consequences (Kraków 1996).

Rosati C. S., 'Some puzzles about objectivity of law' (2004) 23 (3) Law and Philosophy.

Spyra T., Granice wykładni prawa: znaczenie językowe tekstu prawnego jako granica wyktadni, [Boundaries of interpretation of law. Linguistic significance of legal text as a Bondary of interpretation of law] (Kraków, Zakamycze 2006).

Szabó I., Pojęcie stuszności w różnych systemach prawnych [The notion of justice in different legal systems], (1971) 5 Law and State.

Tuleja P., Normatywna treść praw jednostki $w$ ustawach konstytucyjnych $R P$ [The normative content of individual rights in the constitutional laws of Poland] Wydawnictwo Sejmowe (Warszawa 1997).

Weinberger O., 'Prima Facie Ought. A Logical and Methodological Enquiry' (1999) 12 (3) Ratio Juris

Wojciechowski B., 'Dyskursywny model sądowego stosowania prawa wybrane aspekty' [A discursive model of judicial law enforcement - selected aspects] in Jerzy Stelmach (ed), Filozofia prawa wobec globalizmu [Philosophy of law towards globalism] (Kraków 2003).

Woleński J., Epistemologia [Epistemology] (Warszawa, Wydawnictwo Naukowe PWN 2005).

Wyrzykowski M., Pojęcie interesu społecznego $w$ prawie administracyjnym [The notion of social interest in administrative law] (Warszawa 1986).

Zirk-Sadowski M., 'Transformation and Integration of Legal Cultures and Discourses - Poland' in Wojciech Sadurski, Adam Czarnota, Martin Krygier (eds), Spreading Democracy and the Rule of Law (Springer Verlang Berlin 2005).

Zirk-Sadowski M., Community of Judges (paper presented during The 9th International Roundtable for the Semiotics of Law, Poznan, 2010).

Zirk-Sadowski M., Instytucjonalny i kulturowy wymiar integracji prawnej [Institutional and cultural dimension of legal integration] in Leszek Leszczyński, Zmiany społeczne a zmiany w prawie. Aksjologia, konstytucja, integracja europejska [Social changes and legal changes. Axiology, constitution, European integration] (Lublin, 1999) 41;

Zirk-Sadowski M., Interpretation of law and its comprehension in Poland after the EU accession, 12 (paper presented at a conference in Gniezno, 2629.09.

2004).

Galligan D. and Matczak M., Strategie orzekania sadowego. O wykonywaniu władzy dyskrecjonalnej przez sędziów sądów administracyjnych w sprawach gospodarczych $i$ podatkowych [Strategy of judicial decisions. About discretionary power completed by administrative court judges in economic and fiscal cases] (Warszawa 2005). 